OPEN ACCESS

Edited by:

Davide Tiranti,

Agenzia Regionale per la Protezione

Ambientale (ARPA), Italy

Reviewed by:

Mario Parise,

University of Bari Aldo Moro, Italy

Chiara Deangeli,

Politecnico di Torino, Italy

*Correspondence:

Lu Wang

wanglu@scu.edu.cn

Specialty section:

This article was submitted to

Geohazards and Georisks,

a section of the journal

Frontiers in Earth Science

Received: 28 January 2021

Accepted: 28 May 2021

Published: 22 June 2021

Citation:

Yan X-F, Xu H, Lu H, Zhou J-W,

Wang $X-K$ and Wang $L$ (2021)

Assessment and Analysis of a

Rainfall-Time-Lagging Water-Related

Disaster in Mountainous Areas.

Front. Earth Sci. 9:659708.

doi: 10.3389/feart.2021.659708

\section{Assessment and Analysis of a Rainfall-Time-Lagging Water-Related Disaster in Mountainous Areas}

\author{
Xu-Feng Yan ${ }^{1}$, Hui X ${ }^{2}$, Heng $\mathrm{Lu}^{3}$, Jia-Wen Zhou ${ }^{3}$, Xie-Kang Wang ${ }^{1}$ and Lu Wang ${ }^{1 *}$ \\ ${ }^{1}$ State Key Laboratory of Hydraulics and Mountain River Engineering, Sichuan University, Chengdu, China, ${ }^{2}$ National \\ Meteorological Center, Beijing, China, ${ }^{3}$ College of Water Resources and Hydropower, Sichuan University, Chengdu, China
}

Both global climate change and human activities are continuously impacting the abruptness and frequency of water-related natural disasters such as flash floods, debris flows, and landslides in mountainous areas, greatly threatening the safety of lives and properties. A recent rainfall-induced debris flow event happened on July 6, 2020 in the Chenghuangmiao Gully, in Sichuan Province, China, resulting in severe damage to buildings at the outlet. An integrated analysis of the consequence and triggering mechanism of this debris flow event was conducted with hydrologic information, topographic details, vegetation regimes, and drone aerial imagery. The result shows that the entire runout of the debris flow differs from that of common ones (debris flow and rainfall were highly related and synchronized), which happened $4 \mathrm{~h}$ after the stop of the rainfall. The hysteretic feature increases the difficulty of the prediction and warning of the debris flow due to lack of a responsible triggering mechanism. The hillslope surface is well covered by vegetation, hindering regular observation and cleaning up of long-term deposited wood and sediment debris. This effect increases the crypticity and abruptness of potential debris flows. With field evidence and analysis, it is speculated that long-term accumulative processes of dead wood sand sediment deposition formed a small-scale debris dam, and the continuous water release from the watershed led to dam breaching, subsequently triggering the initiation of the debris flow. Multiple steps distributing along the gully of an average slope of $15.65^{\circ}$ contributed to the amplification of the debris flow once the breach of the upstream wood and sediment dam occurred. Along the gully, small-scale landslide scars can be observed, possibly amplifying the scale of the debris flow and disaster impact. This debris event gives a lesson of necessary demands of predicting and managing the risks of a low-frequency debris flow non-synchronized with rainfall events.

Keywords: water-related disaster, rainfall-lagging effect, mountain area, debris dam breaching, fatality

\section{INTRODUCTION}

In the mountainous region of Southwest China, water-related disasters such as flash floods and debris flows represent the most catastrophic hazards, leading to infrastructure damage, property loss, and fatality. Particularly, debris flows due to great destructive effects and abruptness are the most dominant type of hazards, leading to great fatality in China (Lin and Wang, 2018). Because of high gradient in the catchment, debris materials (rocks, cobbles, sands, and soils) are available in ravines 
due to both gravitational erosion and hydraulic erosion, becoming massive sources for debris flows (Yin et al., 2016; Gregoretti et al., 2018). Such physical processes can be amplified by earthquakes with large magnitude (Cui et al., 2011; Huang and Fan, 2013; Horton et al., 2019). An example is that both the frequency and amount of debris flows in and near the earthquake area significantly increased after the dominant 2008 Wenchuan earthquake, with magnitude Ms $=8.0$ as well as 10-year aftershocks (Chen et al., 2012; Tang et al., 2012; Zhang et al., 2014; Hu et al., 2019). Another factor to amplify the debris flow magnitude and increase the frequency is global climate change since extreme rainfall generating intense surface runoffs potentially triggers the initiation of debris flows (Stoffel et al., 2014).

Debris flows can be consequences of different mechanisms. The most common and well-recognized mechanism is that debris flows can result from the coupling effect of shallow landslides and failure of gully saturated floor materials. The collapsed sediment materials due to landslides move onto gully floors with high momentum, entraining gully floor materials whose stability is reduced by increasing water volume content. The increased pore water pressure has also been identified to be able to cause shallow landslides due to the formation of a perched water table, which is essentially associated with rainfall conditions (Vanapalli et al., 1996; Lu and Godt, 2013). Therefore, the rainfall intensity-duration characteristics are favored as indicators of shallow landslides (Vessia et al., 2014; Vessia et al., 2016; Li et al., 2017). As reviewed by Vessia et al. (2014), two types of rainfall intensity-duration thresholds are usually used for determining landslide risks: 1) considering rainfall events that have resulted in landslides excluding antecedent rainfall conditions and 2) considering antecedent rainfall conditions only. The second-type mechanism is that gully beds with deposited sediment tend to be destabilized by hydrodynamic forces exerted by intense rainfall-induced runoff (Gregoretti and Fontana, 2008; Wei et al., 2018) or dam breach-induced flash floods (Cui et al., 2013).

On July 6, 2020, a devastating debris flow disaster happened at 4:00 am in the Chenghuangmiao Gully in Xiaojin County, Sichuan, China (Figure 1). Because of the occurrence, some residents living at the outlet of the gully failed to evacuate timely from the debris flow runout path and died in this disaster. The debris flow buried partially the buildings and farms, depositing over the fan of the gully. According to the interview of local people, debris flow events have not occurred for more than 50 years in this gully, indicating a very low-frequency debris flow recurrence regarding this gully. Another important fact is that the disaster happened $4 \mathrm{~h}$ after the stop of the rainfall, leading residents to lose vigilance and thus resulting in fatality.

This article aimed to give a detailed description of the Chenghuangmiao Gully debris flow, including the geomorphologic characteristics of the catchment, rainfallrunoff process, and depositional morphology. Then we attempt to interpret the initiation mechanism of the debris flow and find the reason for the time delay between the rainfall and debris flow. Finally, a lesson can be learned to better detect and manage such debris flow with a very low frequency.

\section{STUDY BACKGROUND}

\section{Study Area}

The studied debris flow disaster occurred in the Chenghuanmiao Gully, which is a tributary gully to the Xiaojinchuan River, located in Xiaojin County, Sichuan Province, Southwest China $\left(\mathrm{E} 102^{\circ} 10^{\prime} 9.340^{\prime \prime}, \quad \mathrm{N} 31^{\circ} 0^{\prime} 13.870^{\prime \prime}\right)$. As shown in Figure 2, the Chenghuangmiao Gully catchment covers an area of $6.1 \mathrm{~km}^{2}$, with only one gully connecting the catchment head to the outlet. The gully gradient on average is $\sim 28 \%$ (i.e., $15.65^{\circ}$ ), with the gully head elevation $\sim 3,222 \mathrm{~m}$ and outlet elevation $\sim 2,169 \mathrm{~m}$.

Because of the active tectonic and climatic settings on the eastern edge of the Tibet Plateau, the Chenghuangmiao Gully catchment is typically $\mathrm{V}$ shaped, indicating active bedrock incision being balanced by massive landsliding. The 2008 Wenchuan earthquake $(\mathrm{Ms}=8.0)$ and its aftershocks intensified landslide activities and thus soil loss in the ambient area. This catchment subject to Xiaojin County close to the earthquake center has also been significantly affected. As shown in Figure 2C, the northern hillslopes for the
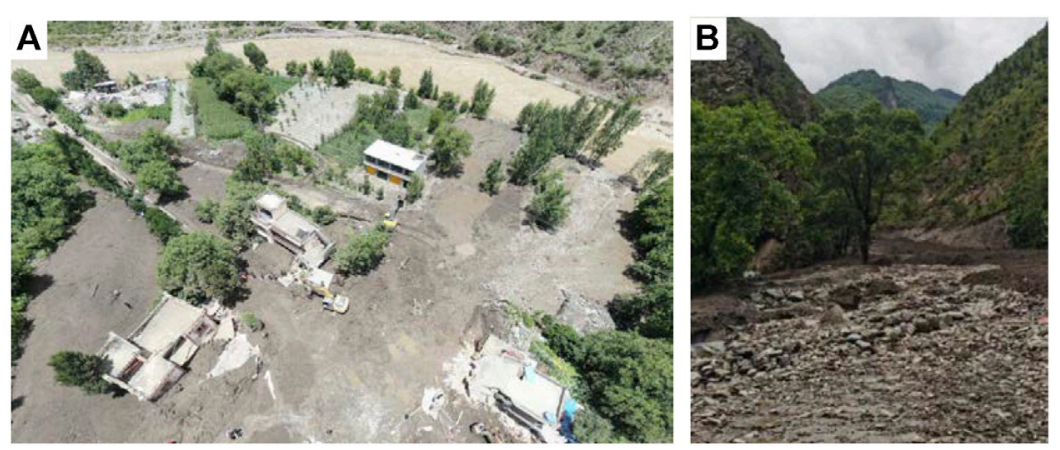

FIGURE 1 | Site photos of the Chenghuangmiao Gully debris flow disaster at the outlet (https://720yun.com/t/38vksbpygp9?scene_id=50391102). (A) Buried houses and farms and (B) large-sized cobbles flushed out from the gully (a photo by the authors). 

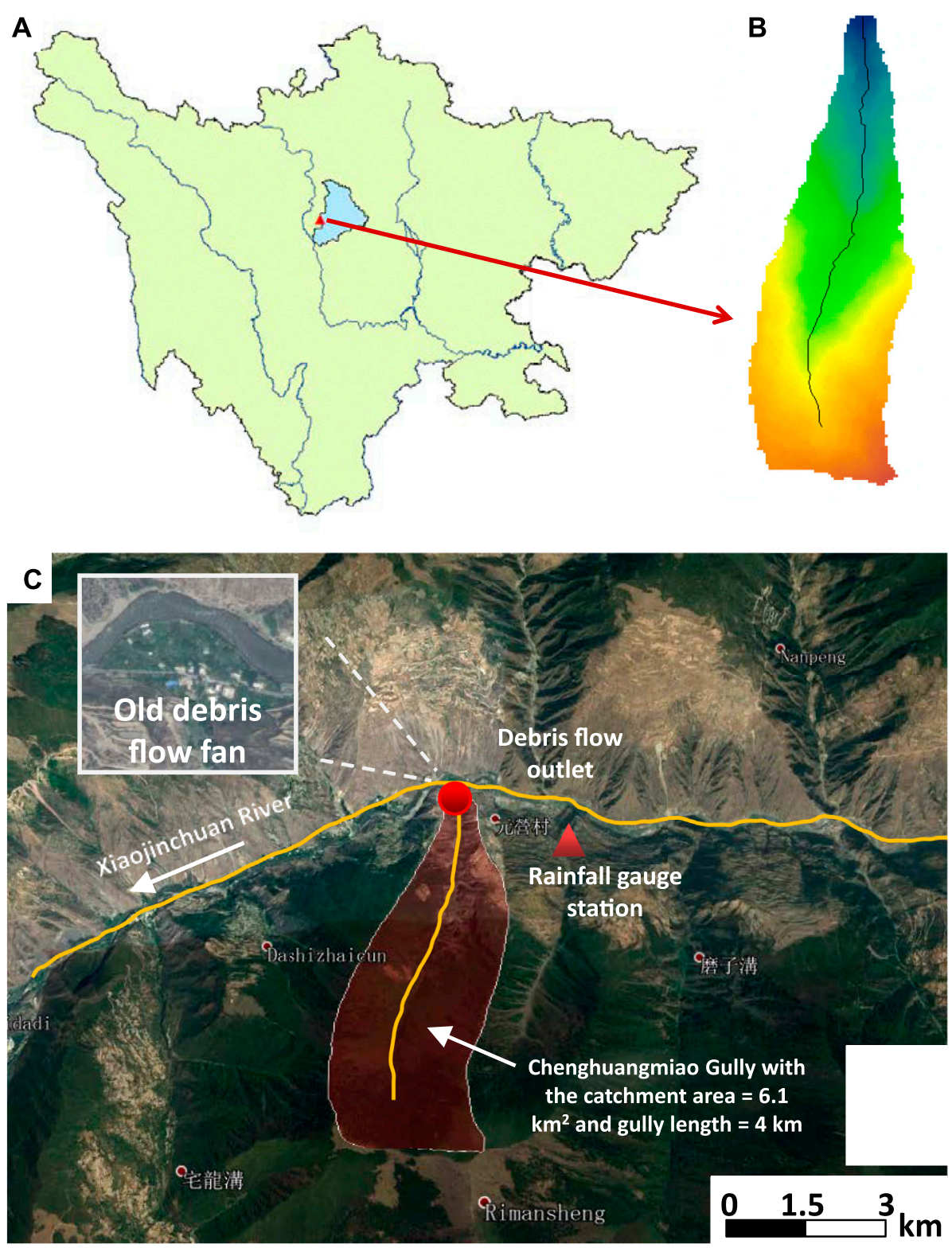

FIGURE 2 | Geomorphic information of the Chenghuanmian Gully catchment. (A) The gully is located in Xiaojin County, Sichuan, China. (B) Only one gully without any subbranch exists in the catchment to convey runoff discharge and sediment to the outlet with higher elevation at south and lower elevation at north. (C) A remote image in 2013 (from Google Earth) demonstrates that the gully is a tributary to the Xiaojingchuan River, and an old debris flow fan has been deposited to squeeze the Xiaojingchuan River, which has been well developed by humans for residence and agricultural activities. The old debris flow fan indicates that historical debris flows happened in the Chenghuangmiao Gully, but the recurrence frequency is low so that humans can organize normal activities on this debris flow fan.

Xiaojinchuan River valley are significantly broken and rarely covered by vegetation due to great steepness in hillslope and landslide effect. However, the southern hillslopes where the Chenghuangmiao Gully catchment is located are relatively complete and well covered by vegetation. This suggests that mountainous hazards such as landslides and debris flows are not frequent in this catchment, giving rise to necessary conditions for human living and agricultural activities in the open area near the outlet, which is a debris flow fan formed in a big timescale.
However, the forced debris flow fan against the Xiaojinchuan River indicates that repeated debris flow events that happen in history might be lowly frequent.

The Chenghuangmiao Gully catchment is well covered by dark brown forest soil and cinnamon soil, which provide good habitats for tall vegetation like forests. Similar to the neighboring catchments on the same side of the Xiaojinchuan River valley, dense tall vegetation covers the landscape in the upstream area (the gully head), while sparse vegetation or even 


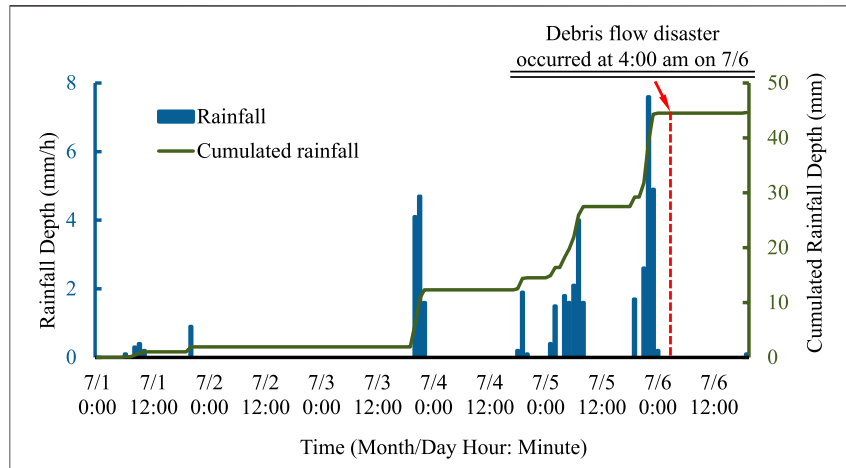

FIGURE 3 | Rainfall characteristics.

no vegetation protects the downstream area near the Xiaojinchuan River. Thus, geomorphic and vegetation characteristics allow more landslides induced by gravitational and hydrodynamic effects to frequently occur in the downstream reach of the catchments, further indicating more loose deposits in the downstream reach of the gully. Furthermore, because human activities are closer to the river valley, land use on the hillslopes is more common in the downstream part. This will also lead to relative potentials of landslides and soil loss.

\section{Chenghuangmiao Gully Debris Flow Disaster}

Prior to the Chenghuangmiao Gully debris flow disaster, rainfall had remained for a long time and accumulated widely in the mountainous area in Sichuan in the past month (June 2020), including heavy rainstorms. On July 5, the rainfall was intensive at night and continued for several hours before its ending near 24:00. In this duration, the local residents who were living in the open area at the outlet of the Chenghuanmiao Gully (an old debris flow fan) were asked to be alert in case of flash floods. According to the local residents and government, no debris flow event had been recorded for decades, while flash floods were frequent under heavy rainstorms. After 0:00 on July 6, the rainfall decreased progressively, and the flow discharge drained from the gully as well. Therefore, the alert residents returned to their homes and fell asleep, unless one or two people were still monitoring the rainfall and runoff.

At 4:00 am, a high-energy debris flow suddenly arrived at the resident living place, brutally ruining buildings on the way of the debris flow and finally depositing on the old debris flow fan. According to the recall of the local witness, no special accidents happened as usual, as the rainfall intensity did not increase again. However, the discharge had increased apparently before the disaster. A preliminary speculation is that at the gully head, a dam breach might have happened, triggering flash floods and thus the initiation of debris flow. The reasoning is that the rainfall had stopped for nearly $4 \mathrm{~h}$ and the runoff discharge apparently increased without heavy rain in the small catchment before the debris flow disaster.

\section{Rainfall Characteristics}

Heavy rainfall or even rainstorms occurred in the mountainous area widely over Sichuan Province on the day before the debris flow disaster. Rainfall events with a cumulated 24-h depth greater than $50 \mathrm{~mm}$ were monitored in 31 rain gauge stations within 11 counties. Particularly, rainfall events with cumulated 24-h depth higher than $50 \mathrm{~mm}$ happened at four stations in two counties. These recorded rainfalls are close to or far greater than the threshold that triggering the debris flows based on rainfallduration threshold $(=50 \mathrm{~mm})$ regressed from average annual rainfall-debris flow data after the 2008 Wenchuan earthquake (Guo et al., 2016).

However, basin hydrologic data show that the cumulated rainfall had reached $314.6 \mathrm{~mm}$ in depth since the flood season. This number exceeds the average annual rainfall by $27.4 \%$ and the same period last year by $90.2 \%$. The long-period rainfall might lead to an adequate saturation of loose materials on hillslopes and channel floors, setting an initiation condition of shallow landslides and debris flows.

The peak rainfall $(=7.5 \mathrm{~mm})$ happened at 22:00 on July 5 and rapidly decayed to zero at 00:00 on July 6 . After $4 \mathrm{~h}$, the debris flow front reached the debris flow fan, destroying and burying several buildings and farms and tragically killing three lives of sleeping residents. It can be observed that the rainfall depth in this studied catchment was $29.8 \mathrm{~mm}$ for the 24-h rainfall depth and was $7.5 \mathrm{~mm}$ for hourly rainfall depth (Figure 3), which were far lower than the rainfall-duration thresholds $(50 \mathrm{~mm})$.

\section{RESULTS AND ANALYSES}

\section{Runoff Generation}

To evaluate whether the rainfall-induced discharge during the past $24 \mathrm{~h}$ could impact the mobilization of deposited debris on the gully floor, a semi-distributed hydrologic model was employed to simulate the catchment rainfall-runoff process. The model is based on the concept of the geomorphologic instantaneous unit hydrograph (GIUH), which was initially developed by Rodriguez (Rodríguez-Iturbe and Valdes, 1979; Lee and Yen, 1997; Yen and Lee, 1997). The kinematic-wave module was introduced to simulate the travel time of flow based on a stream-ordering method. Regarding the model, rainfall is assumed to be distributed uniformly over the simulated

TABLE 1 | Geomorphic parameters of the Chenghuangmiao Gully catchment.

Parameter
Catchment relief $(\mathrm{m})$
Catchment area $\left(\mathrm{km}^{2}\right)$
Perimeter $(\mathrm{m})$
Gully length $(\mathrm{m})$
Gully relief $(\mathrm{m})$
Depositional volume $\left(\mathrm{m}^{3}\right)$
Runout distance $(\mathrm{m})$




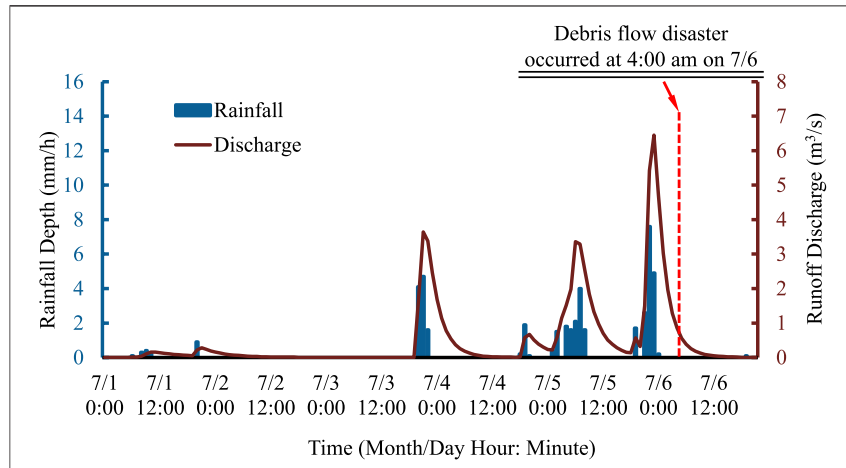

FIGURE 4 | Simulated rainfall-runoff processes.

catchment. An outflow hydrograph for the catchment outlet is produced by tracing the motion history of the rainfall (the raindrops). In the model, the needed geomorphologic features can be statistically obtained from the digital elevation model (DEM) through ArcGIS. The total instantaneous unit hydrograph is then calculated in overland regions and stream regions, respectively. The resistance effect of surfaceflow roughness to the runoff path is determined by roughness pattern for hillslopes and streams, respectively, which is simply parameterized by surface roughness coefficients. The model applications for the prediction of rainfall-runoff processes in mountainous catchments can be found in the study by Lee and Yen (1997), Huang and Lee (2013), and Huang et al. (2016). The employed model parameters as input are summarized in Table 1.

As shown in Figure 4, the rainfall-runoff coupling process is presented. It can be found that a global runoff discharge peak $\left(=6.45 \mathrm{~m}^{3} / \mathrm{s}\right)$ at $23: 00$ on July 5 just followed the rainfall peak at 22:00 on July 5 . Within $4 \mathrm{~h}$, the runoff discharge rapidly decreased to $0.85 \mathrm{~m}^{3} / \mathrm{s}$ at $4: 00$ on July 6 , when the debris flow disaster took place. Therefore, it is important to know where the peak discharge can mobilize a boulder of grain size $=2 \mathrm{~m}$ or initiate the debris flow. Simply by applying the Manning equation, the following equation can be obtained:

$$
Q=\frac{1}{n} \times A \times R^{\frac{2}{3}} \times \sqrt{S},
$$

where $Q=$ discharge, $A=$ cross-sectional area, $R=$ hydraulic radius, and $S=$ bed gradient. Then the mean velocity $U$ can be estimated as follows:

$$
U=\frac{Q}{A}
$$

An error and trial procedure is applied to estimate $U$, with $n=$ $0.04, S=0.28$, and assuming the average width $B=3-8 \mathrm{~m}$ and water depth $H=1-2 \mathrm{~m}$. Finally, the calculation gives the yield of $U=0.29-1.16 \mathrm{~m} / \mathrm{s}$, which can hardly mobilize a boulder of grain size $=2 \mathrm{~m}$. The velocity magnitude may be the cause mechanism for high-frequency debris flows (with a return period of 3-5 years under a snowmelt geological context) (Gregoretti and Fontana, 2008; Pastorello et al., 2020). However, it was not likely to initiate a debris flow of such a low frequency well covered by vegetation in the current case. The analysis of flow velocity indirectly confirms that the only possible cause responsible for the debris flow is dam breach-induced flash flood at the gully head.

\section{Catchment Geomorphic Characteristics and Landslide Scar Distribution}

As already stated, the Chenghuangmiao Gully as only a single branch is embedded in a small catchment $\left(6.1 \mathrm{~km}^{2}\right.$ in area). As shown in Figure 5, this catchment is long and narrow, with a shape index (relief width to length ratio) of $\sim 0.47$. Therefore, compared with the catchment with a high aspect ratio, the runoff has a long path on the gully floor. Based on a digital elevation model (DEM), the gully starts at its highest elevation of $\sim 3,669 \mathrm{~m}$ and the lowest elevation of $\sim 2,184 \mathrm{~m}$, yielding the gully gradient of $\sim 28 \%$.

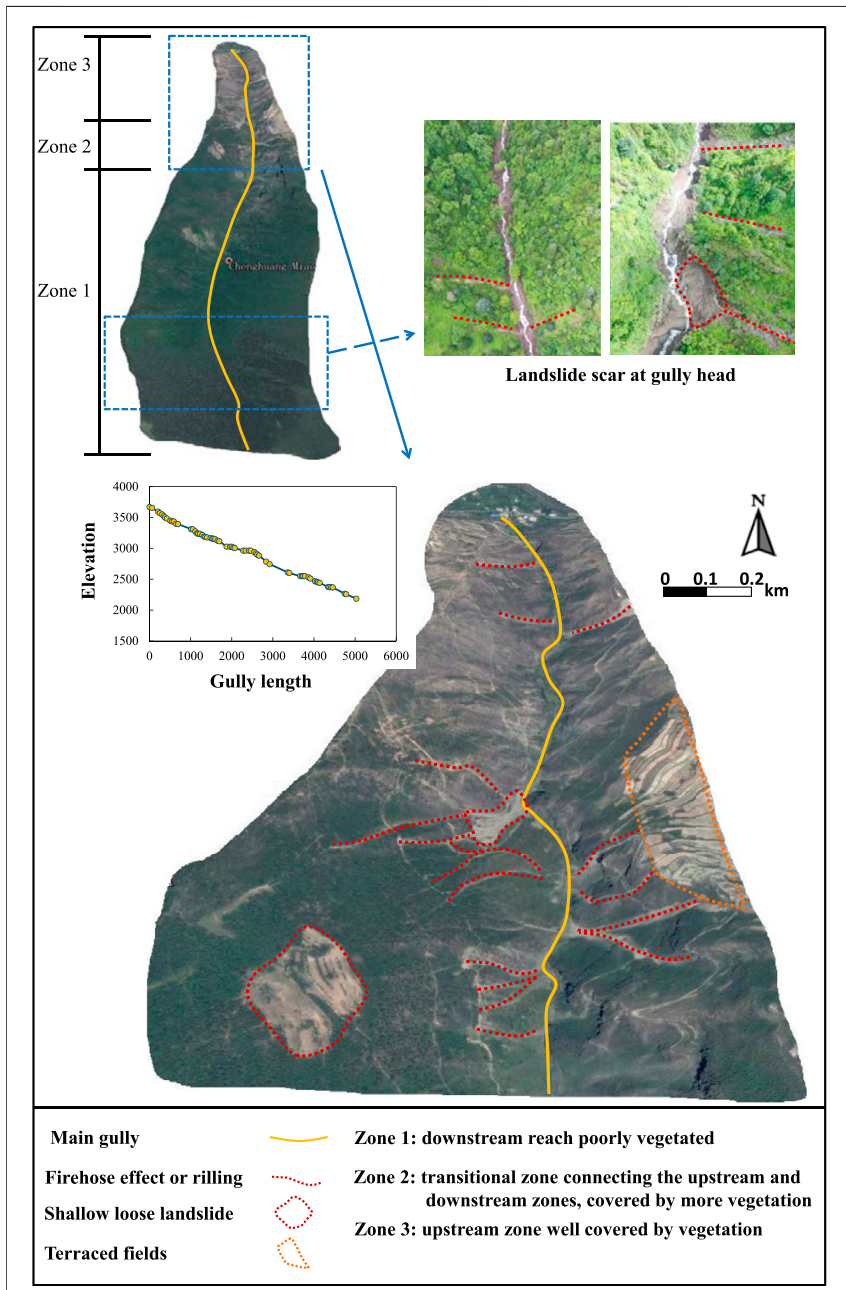

FIGURE 5 | Satellite images (from Google Earth) showing the fundamental hillslope surface conditions of the Chenghuangmiao Gully catchment (in 2014). The entire catchment is typically divided into three zones based on vegetative coverage. 
Unlike those gullies of high-frequency debris flows (Tiranti and Deangeli, 2015), this gully is relatively well covered by vegetation. It is visually observed that the entire catchment can be divided into three zones according to the vegetation coverage status. In Zone 1, starting from the gully head, the catchment hillslopes are well covered by trees, protecting the hillslope surface from being eroded. Only scattered small landslide scars (rills) occur. This suggests that the gully floor loose materials mainly constitute dead vegetation and a small number of sediment particles. Zone 2 is a transition zone to link the upstream and downstream reaches. In this zone, vegetation coverage becomes lower and vegetation is more made up of shrubs and bushes. As a result, frequent landslide scars (including rill scars and wide large scars) within the vegetation cover can be identified on both sides of the catchment hillslopes, providing a large number of loose materials on the gully floor and potential loose material source from existing landslide scars. Particularly, on the right ridge of the catchment (looking downward), a large area of terraced fields is existent, which may provide sources of loose materials and risk in landslide (Garfi et al., 2007; Schilirò et al., 2018). For Zone 3, the hillslope surface becomes barer, poorly covered by vegetation (grasses or crops). Loose materials are easier to move into the gully floor from surface hydraulic erosion or landslides.

Therefore, it can be concluded that both the loss of vegetation protection and human inferences over the downstream reach of the catchment (less than $1 / 3$ of the total length) lead to the formation of the loose materials on the gully floor. However, the area percentage is so small that the storage of the gully floor loose materials needs a long time to reach its threshold for the initiation of the debris flow in this gully.

\section{Debris Flow Formation Mechanism and Behavior}

According to the field investigation, three zones characterizing the formation and evolutionary process of the debris flow can be recognized. Because of the steep geomorphology of the gully, it was difficult to access the upstream reach, and drone imagery photos immediately after the debris flow disaster are used for the assessment.

A basic fact is that the Chenghuangmiao Gully debris flow was not initiated during the rainfall event of the past $24 \mathrm{~h}$. The peak discharge and bulk velocity of the runoff estimated from the rainfall process are insufficiently high, which can initiate the debris flow and entrain the largest boulder to the outlet deposit fan. Therefore, the Chenghuangmiao Gully debris flow is a typical delayed one, which was formed by the post-rainfall mechanisms. Herein, two possible mechanisms can be adopted as candidate causes for the initiation of the debris flow.

The first possible cause is that the delayed debris flow might be initiated by delayed landslides at the upstream reach after the stop of the rainfall. Although the rainfall stopped, water continuously infiltrated the hillslope colluvium. This enabled the continuous increase in pore pressure and water volume content of the hillslope colluvium. Once the colluvium was saturated and the pore pressure exceeded the threshold condition for the hillslope stability, delayed landslides highly possibly happened. The failed sediment, soil, and rock then transform into a liquefied solid-flow mixture with high pore-fluid pressure (Bogaard and Greco, 2016), resulting in a delayed debris flow event. The landslide-induced debris initiation mechanism has been identified widely from the past debris flow events (Iverson et al., 1997; Kritikos and Davies, 2015; Gao et al., 2017). The delayed landslides have been reported in the previous filed studies as well (Lollino et al., 2011; Zhang and $\mathrm{Li}$, 2018). However, landslide-triggered debris flow almost happened during the rainstorm instead of $4 \mathrm{~h}$ after the stop of rainfall regarding the current case. The basin hydrologic data show that the cumulated rainfall for the flood season exceeds that of the same period last year by $90.2 \%$. This fact could be considered an indication of occurrence of significant landslide activities on the side slopes of the catchment to meet the secondtype rainfall intensity-duration threshold classified by Vessia et al. (2014). Because of the difficulty in accessing the upper part, the landslides which directly triggered this debris flow event were not found, unfortunately.

The second cause of high possibility is that post-rainfall dambreach runoff might initiate the debris flow. It is highly suspected that a landslide happened at the head reach of the gully after the stop of the rainfall. Collapsed loose sediment particles and dead woods together dammed the narrow gully floor to form a barrier water body. Even though the rainfall stopped, runoffs were continuously generated from the hillslopes. Eventually, the barrier structure could not sustain the increasing high pore pressure and failed. The probable residual imprint of dam breach was observed: mixed rocks, sands, slurries, and dead woods were still existent on the two banks of the gully floor at the head reach, and an eroded subchannel was formed after the dam failure (Figure 6). Although the volume of the barrier dam might not be large, the steep topography of the gully floor and the long path for the evolution of the flash flood could amplify the erosion energy for the gully deposits at downstream, where landslide scars increasingly grow on the hillslopes. As a result, the transportation zone of debris flow was formed. In this zone, the gully deposits have accumulated for decades since no debris flow happened in this period. Particularly, the total rainfall amount higher than average annual might lead the loose deposits to a completely saturated status, resulting in bed failure under the dam breach flash flood. Along the transportation zone, more and more loose materials were set in motion, increasing the erosive energy of the debris flow. Therefore, the historical deposits at the further downstream reach tended to be eroded down to the bedrock.

Although the dam breach event was not observed at midnight, the flow rate at the gully outlet became high without rainfall as stated by a witness. This may indirectly support the mechanism of the dam-breach flood triggering the debris flow. In fact, dambreach-triggered debris flows have been reported in a number of debris flow studies (Breien et al., 2008; Cui et al., 2013; Hu et al., 2016), which were reported to be highly dangerous.

At the end of the gully, the debris flow carrying massive sediment materials tended to deposit due to the decrease in the gully bed slope, the absence of valley confinement, and the obstruction of buildings in the sediment deposition zone 

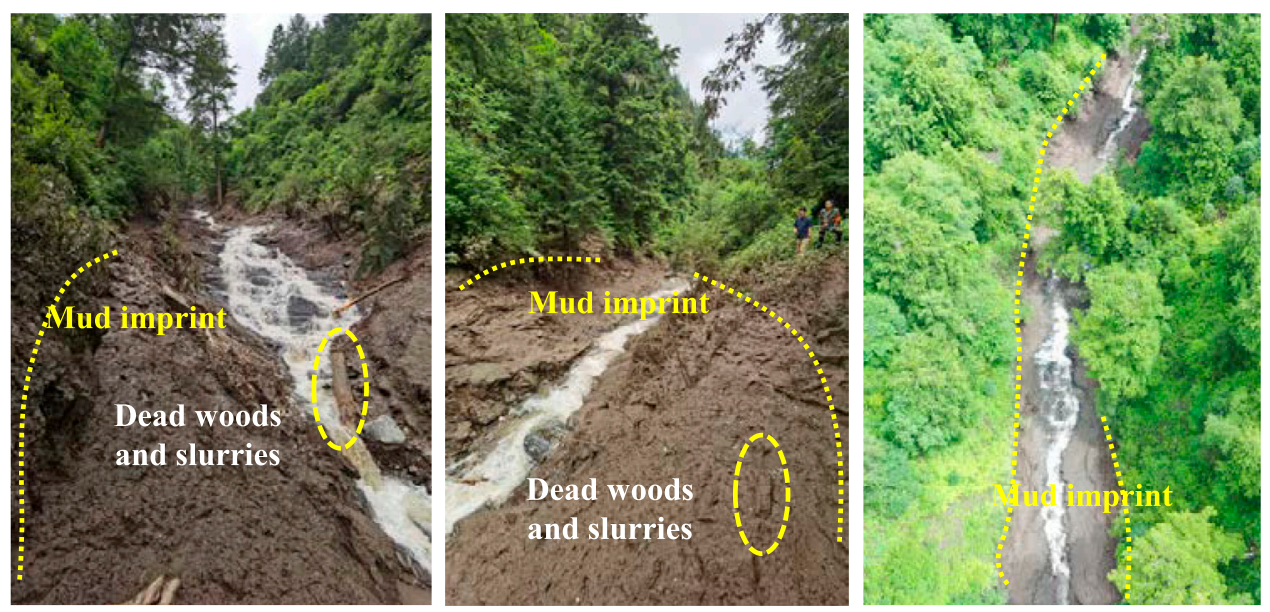

\section{Head reach - initiation zone}
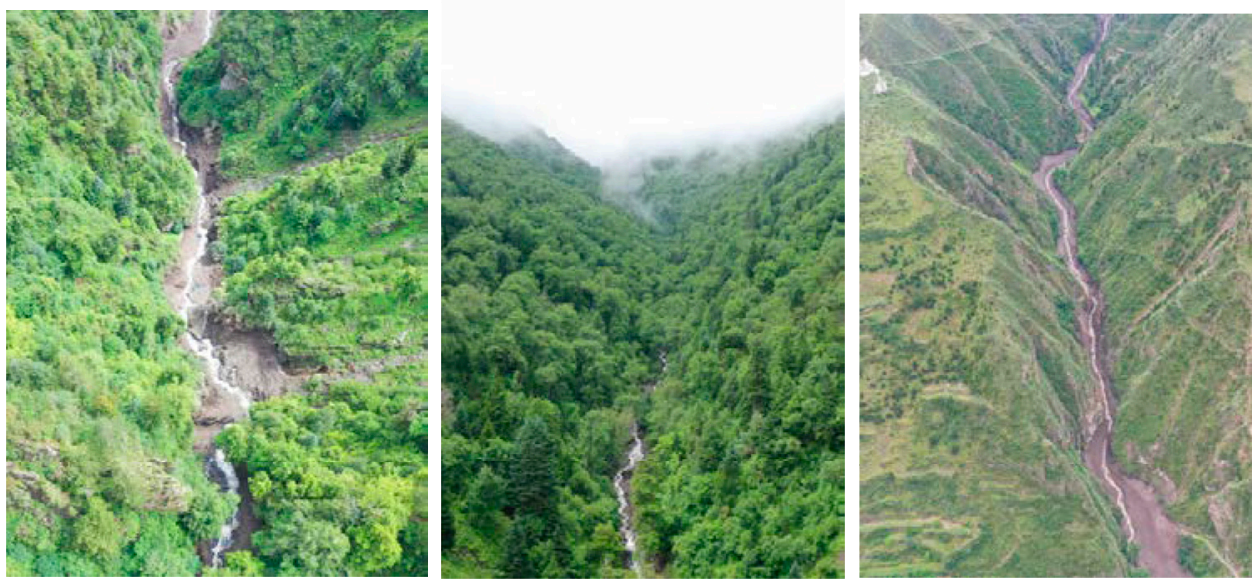

Middle reach - transportation zone

FIGURE 6 | Drone imageries showing the debris flow path in the initiation zone and transportation zone.

(debris fan). Compared with the old debris flow fan (fan area = $0.0462 \mathrm{~km}^{2}$ ), the new depositional area, mainly distributing on the right side, accounts for nearly $3 / 4$ of the total area. This is because previous main debris flows brought big amounts of depositional materials to aggrade the fan on the left side, resulting in transverse gradient on the fan (a clear geomorphologic feature observed in the field). This characteristic of the deposition dynamics that the deposition zone alternates periodically is common.

Zoning regarding the debris particle size is evidentially identified on the debris flow fan. A narrow coarse band constituted of rocks, boulders, and gravels (Figures 7B,D) distributed in the middle of the new fan layer. The coarsest particle is nearly $2 \mathrm{~m}$ in length (Figure 7C), and the mean particle size of the narrow band is estimated as $15 \mathrm{~cm}$. Fine particles mainly constituted of sands, slurries, muds, deadwoods, and scattered gravels distributed on the sides of the fan. Functionally, the coarse particles characterized by high momentum and energy lead the main path of the debris flow, and the fine particles due to the greater spatial dispersive effect tend to transversely cover the fan.
Therefore, two types of disasters on the debris flow deposition fan can be identified. One kind of disaster is that buildings, farms, roads, and trees were totally smashed out and destroyed by the high-energy main stream of the debris flow with coarse particles since these objects obstruct the debris flow path (Figures 7A,B). The other type is that the lateral moving debris flow due to diffusive effect on the fan buries parts of buildings, farms, and roads. These particles are generally fine with small velocities. Therefore, the damage impact of the second kind can be much less pronounced by the first-type disaster.

\section{DISCUSSION: A LESSON FROM THE 7.6 CHENGHUANGMIAO GULLY DEBRIS FLOW DISASTER}

It should be noted that the debris flow disaster happened $4 \mathrm{~h}$ after the stop of the rain. This kinematic behavior solidly indicates that this 

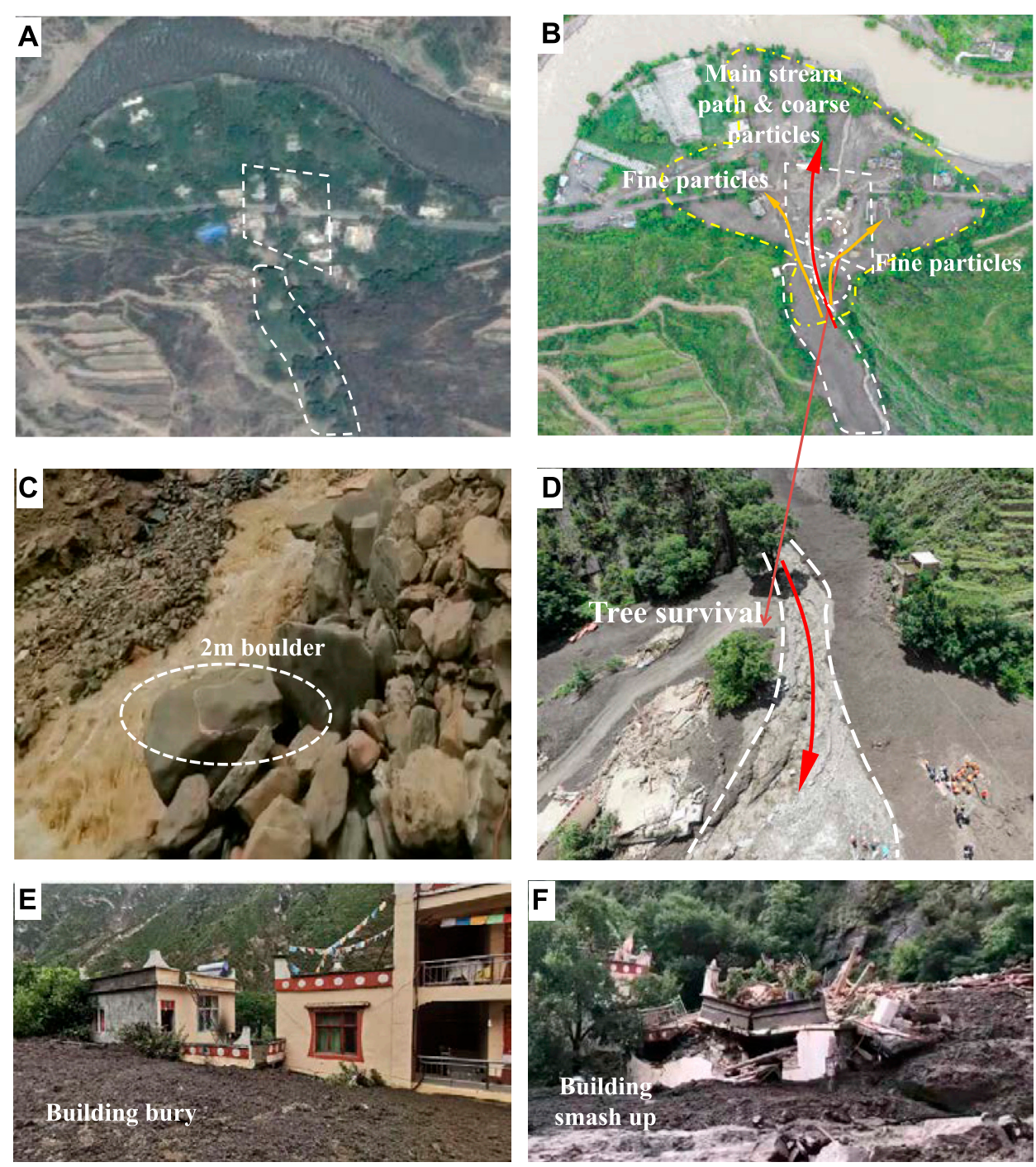

FIGURE 7| Photos of deposition characteristics of the 7.6 Chenghuangmiao Gully debris flow by drone and satellite at different times. (A) Pre-debris flow disaster in Feb 2014 (from Google Earth), (B) post-debris flow disaster on July 7, 2020, (C) the cross sections of the transportation zone of the debris flow, and (D) a close look of the different-sized deposition areas of the debris flow.

debris flow was initiated by a delayed shallow landslide or dam breach flash flood as analyzed. By observing the transportation path of the debris flow, it is easily known that the initiation site is deep in the catchment gully, which is difficultly found out before the occurrence of the debris flow disaster. In fact, the Chenghuangmiao Gully is an old debris flow gully due to the formation of the debris flow fan at the gully mouth. Because of the low frequency nature, the probability of reoccurrence of a debris flow does not draw adequate attention by the local government and residents. People have conducted decadal living and agricultural activities on this debris flow fan.

Under the background of post-earthquake period, the socalled low-frequency debris flow is expected to be active compared with that for the pre-earthquake period. Therefore, to enhance the monitoring of the gully condition and evaluate the occurrence probability of low-frequency debris flow are crucial to human live safety and property safety for similar gullies.

\section{Hysteretic Nature}

Such a relatively long time lag $(4 \mathrm{~h})$ to the rainfall is not typical for a debris flow (Santi et al., 2011). Residents took refuge during the rainfall, trying to avoid the rainfall-triggered flash flood and debris flow. According to experiences, the potential risk of debris flows only increased during the rainfall period. The residents realized the disaster risk released after the ending of the rainfall as usual and returned to their homes till the arrival of the debris flow. The sleeping people were not able to evacuate.

\section{Abruptness Nature}

Debris flows had not occurred for several decades so that people could construct homes and agricultural activity on the stable 
debris flow fan of the Chenghuangmiao Gully. This leads to a mistake understanding of the generation of the debris flow activity in this gully. Loose sediment materials due to smallscale landslides and hydraulic erosion deposited on the gull floor decade after decade. With a triggering condition (e.g., shallow landslides or dam breach runoff), a debris flow event was finally initiated. No special early warning and monitor techniques such as rainfall intensity-duration thresholds and monitor sensors are available to predict the recurrence time and performance of this delayed debris flow characterized by a very low frequency. Furthermore, the 24-h accumulated rainfall was only $17 \mathrm{~mm}$, which was not significant for a mountainous gully in a catchment of $\sim 6 \mathrm{~km}^{2}$. All the above factors led to the abruptness of this debris flow disaster.

\section{Crypticity Nature}

It is highly suspected that a delayed shallow landslide or dam beach event deep in the gully triggered the mobilization of gully debris deposit. The breach location is at the reach well covered by vegetation, where the landslide dam was difficultly identified. This results in the fact that even the residents and government may be aware of the possibility of the debris flow. The cause or initiation mechanism (landslide dam) is still not clear. Furthermore, the gully and catchment are small (no branch, $3.86 \mathrm{~km}$ in length, and $6 \mathrm{~km}^{2}$ in catchment area), and the upstream is well covered by vegetation, which leads to the illusion that a large destructive debris flow cannot happen in this type of gully.

\section{CONCLUSION}

With global climate change and human interference, waterrelated disasters have been recognized to be amplified and more frequent. The rainfall-induced debris flow is one most typical category among those disasters. This article reported a tragic rainfall-induced debris flow, which happened at 4:00 am on July 6, 2020. This disaster event led to the loss of three sleeping lives and destroying several homes at the Chenghuangmiao Gully. After a field investigation and analysis of rainfall data, a conclusion can be drawn that the disaster was caused by a delayed low-frequency debris flow triggered by a gully head shallow landslide or dam breach flash flood. The delayed debris flow disaster is the result of the geomorphic characteristics of the elongated V-shaped catchment

\section{REFERENCES}

Bogaard, T. A., and Greco, R. (2016). Landslide Hydrology: From Hydrology to Pore Pressure. Wiley Interdisciplinary Rev.: Water 3, 439-459.

Breien, H., De Blasio, F. V., Elverhøi, A., and Høeg, K. (2008). Erosion and Morphology of a Debris Flow Caused by a Glacial lake Outburst Flood, Western Norway. Landslides. 5, 271-280. doi:10.1007/s10346-0080118-3

Chen, H. X., Zhang, L. M., Chang, D. S., and Zhang, S. (2012). Mechanisms and Runout Characteristics of the Rainfall-Triggered Debris Flow in Xiaojiagou in determined by the hillslope vegetation cover characteristics, landslide scar distribution, and land use by humans. Three zones distributing along the gully can be easily found to account for the formation of debris flow, including initiation, transportation, and deposition. The analysis of rainfall and runoff shows that the rainfall was not able to mobilize the coarsest boulder or initiate the debris flow and supports that the most possible cause is gully head shallow landslide or dam breach flash flood, for which rainfall intensity-duration thresholds are invalid for prediction. Characterized by hysteretic, abruptness, and crypticity natures, the Chenghuanmiao Gully debris flow disaster led to a severely catastrophic consequence. A lesson can be learned that special attention should be paid to those low-frequency debris flow gullies. Under the impact of frequent earthquakes, the frequency of debris flow might be increased. Once happening, the low-frequency debris flow is most likely to lead to severe hazards. Therefore, these gullies need special investigation and monitoring of the loose deposits and hillslope landslides.

\section{DATA AVAILABILITY STATEMENT}

The raw data supporting the conclusions of this article will be made available by the authors, without undue reservation.

\section{AUTHOR CONTRIBUTIONS}

X-FY: writing-original draft, investigation, funding acquisition, methodology, and software; HX: conceptualization, funding acquisition, and supervision; HL: investigation; J-WZ: methodology and supervision; X-KW: conceptualization, funding acquisition, and supervision; LW: writing-review and editing, conceptualization, and investigation.

\section{FUNDING}

This research was supported by the National Key R\&D Program of China (2019YFC1510702), the National Natural Science Foundation of China (51639007 and 51909178), and the Open Foundation project (SKHL1913), State Key Laboratory of Hydraulics and Mountain River Engineering, Sichuan University.

Sichuan Province, China. Nat. Hazards. 62, 1037-1057. doi:10.1007/s11069012-0133-5

Cui, P., Chen, X.-Q., Zhu, Y.-Y., Su, F.-H., Wei, F.-Q., Han, Y.-S., et al. (2011). The Wenchuan Earthquake (May 12, 2008), Sichuan Province, China, and Resulting Geohazards. Nat. Hazards. 56, 19-36. doi:10.1007/s11069-009-9392-1

Cui, P., Zhou, G. G. D., Zhu, X. H., and Zhang, J. Q. (2013). Scale Amplification of Natural Debris Flows Caused by Cascading Landslide Dam Failures. Geomorphol. 182, 173-189. doi:10.1016/j.geomorph.2012.11.009

Gao, Y., Yin, Y., Li, B., Feng, Z., Wang, W., Zhang, N., et al. (2017). Characteristics and Numerical Runout Modeling of the Heavy Rainfall-Induced Catastrophic Landslide-Debris Flow at Sanxicun, Dujiangyan, China, Following the 
Wenchuan Ms 8.0 Earthquake. Landslides. 14, 1361-1374. doi:10.1007/s10346016-0793-4

Garfí, G., Bruno, D. E., Calcaterra, D., and Parise, M. (2007). Fan Morphodynamics and Slope Instability in the Mucone River basin (Sila Massif, Southern Italy): Significance of Weathering and Role of Land Use Changes. Catena. 69, 181-196. doi:10.1016/j.catena.2006.06.003

Gregoretti, C., Degetto, M., Bernard, M., and Boreggio, M. (2018). The Debris Flow Occurred at Ru Secco Creek, Venetian Dolomites, on 4 August 2015: Analysis of the Phenomenon, its Characteristics and Reproduction by Models. Front. Earth Sci. 6, 80. doi:10.3389/feart.2018.00080

Gregoretti, C., and Fontana, G. D. (2008). The Triggering of Debris Flow Due to Channel-Bed Failure in Some alpine Headwater Basins of the Dolomites: Analyses of Critical Runoff. Hydrol. Process. 22, 2248-2263. doi:10.1002/ hyp. 6821

Guo, X., Cui, P., Li, Y., Ma, L., Ge, Y., and Mahoney, W. B. (2016). Intensityduration Threshold of Rainfall-Triggered Debris Flows in the Wenchuan Earthquake Affected Area, China. Geomorphol. 253, 208-216. doi:10.1016/ j.geomorph.2015.10.009

Horton, A. J., Hales, T. C., Ouyang, C., and Fan, X. (2019). Identifying postearthquake Debris Flow hazard Using Massflow. Eng. Geology. 258, 105134. doi:10.1016/j.enggeo.2019.05.011

Hu, W., Dong, X. J., Xu, Q., Wang, G. H., Van Asch, T. W. J., and Hicher, P. Y. (2016). Initiation Processes for Run-Off Generated Debris Flows in the Wenchuan Earthquake Area of China. Geomorphol. 253, 468-477. doi:10.1016/j.geomorph.2015.10.024

Hu, X., Hu, K., Tang, J., You, Y., and Wu, C. (2019). Assessment of Debris-Flow Potential Dangers in the Jiuzhaigou Valley Following the August 8, 2017, Jiuzhaigou Earthquake, Western China. Eng. Geology. 256, 57-66. doi:10.1016/ j.enggeo.2019.05.004

Huang, J-K., Chan, Y-H., and Lee, K. T. (2016). Real-time Flood Forecasting System: Case Study of Hsia-Yun Watershed, Taiwan. J. Hydrologic Eng. 21, 05015031. doi:10.1061/(asce)he.1943-5584.0001322

Huang, P.-C., and Lee, K. T. (2013). An Efficient Method for DEM-Based Overland Flow Routing. J. Hydrol. 489, 238-245. doi:10.1016/j.jhydrol.2013.03.014

Huang, R., and Fan, X. (2013). The Landslide story. Nat. Geosci. 6, 325-326. doi:10.1038/ngeo1806

Iverson, R. M., Reid, M. E., and LaHusen, R. G. (1997). Debris-flow Mobilization from Landslides. Annu. Rev. Earth Planet. Sci. 25, 85-138. doi:10.1146/ annurev.earth.25.1.85

Kritikos, T., and Davies, T. (2015). Assessment of Rainfall-Generated Shallow Landslide/debris-Flow Susceptibility and Runout Using a GIS-Based Approach: Application to Western Southern Alps of New Zealand. Landslides. 12, 1051-1075. doi:10.1007/s10346-014-0533-6

Lee, K. T., and Yen, B. C. (1997). Geomorphology and Kinematic-Wave-Based Hydrograph Derivation. J. Hydraulic Eng. 123, 73-80. doi:10.1061/(asce)07339429(1997)123:1(73)

Li, W., Liu, C., Scaioni, M., Sun, W., Chen, Y., Yao, D., et al. (2017). Spatiotemporal Analysis and Simulation on Shallow Rainfall-Induced Landslides in China Using Landslide Susceptibility Dynamics and Rainfall I-D Thresholds. Sci. China Earth Sci. 60, 720-732. doi:10.1007/s11430-0169008-4

Lin, Q., and Wang, Y. (2018). Spatial and Temporal Analysis of a Fatal Landslide Inventory in China from 1950 to 2016. Landslides. 15, 2357-2372. doi:10.1007/ s10346-018-1037-6

Lollino, P., Santaloia, F., Amorosi, A., and Cotecchia, F. (2011). Delayed Failure of Quarry Slopes in Stiff Clays: the Case of the Lucera Landslide. Géotechnique 61, 861-874. doi:10.1680/geot.8.p.160

Lu, N., and Godt, J. W. (2013). Hillslope Hydrology and Stability. Cambridge University Press. doi:10.1017/cbo9781139108164

Pastorello, R., D'Agostino, V., and Hürlimann, M. (2020). Debris Flow Triggering Characterization through a Comparative Analysis Among Different Mountain Catchments. Catena. 186, 104348. doi:10.1016/j.catena.2019.104348
Rodríguez-Iturbe, I., and Valdes, J. B. (1979). The Geomorphologic Structure of Hydrologic Response. Water Resour. Res. 15, 1409-1420. doi:10.1029/ WR015i006p01409

Santi, P. M., Hewitt, K., VanDine, D. F., and Barillas Cruz, E. (2011). Debris-flow Impact, Vulnerability, and Response. Nat. Hazards 56, 371-402. doi:10.1007/ s11069-010-9576-8

Schilirò, L., Cevasco, A., Esposito, C., and Mugnozza, G. S. (2018). Shallow Landslide Initiation on Terraced Slopes: Inferences from a Physically Based Approach. Geomatics, Nat. Hazards Risk. 9, 295-324. doi:10.1080/ 19475705.2018.1430066

Stoffel, M., Mendlik, T., Schneuwly-Bollschweiler, M., and Gobiet, A. (2014). Possible Impacts of Climate Change on Debris-Flow Activity in the Swiss Alps. Climatic Change. 122, 141-155. doi:10.1007/s10584013-0993-z

Tang, C., van Asch, T. W. J., Chang, M., Chen, G. Q., Zhao, X. H., and Huang, X. C. (2012). Catastrophic Debris Flows on 13 August 2010 in the Qingping Area, Southwestern China: the Combined Effects of a strong Earthquake and Subsequent Rainstorms. Geomorphol. 139-140, 559-576. doi:10.1016/ j.geomorph.2011.12.021

Tiranti, D., and Deangeli, C. (2015). Modeling of Debris Flow Depositional Patterns According to the Catchment and Sediment Source Area Characteristics. Front. Earth Sci. 3, 8. doi:10.3389/feart.2015.00008

Vanapalli, S. K., Fredlund, D. G., Pufahl, D. E., and Clifton, A. W. (1996). Model for the Prediction of Shear Strength with Respect to Soil Suction. Can. Geotech. J. 33, 379-392. doi:10.1139/t96-060

Vessia, G., Parise, M., Brunetti, M. T., Peruccacci, S., Rossi, M., Vennari, C., et al. (2014). Automated Reconstruction of Rainfall Events Responsible for Shallow Landslides. Nat. Hazards Earth Syst. Sci. 14, 2399-2408. doi:10.5194/nhess-142399-2014

Vessia, G., Pisano, L., Vennari, C., Rossi, M., and Parise, M. (2016). Mimic Expert Judgement through Automated Procedure for Selecting Rainfall Events Responsible for Shallow Landslide: a Statistical Approach to Validation. Comput. Geosciences. 86, 146-153. doi:10.1016/ j.cageo.2015.10.015

Wei, Z.-l., Xu, Y.-P., Sun, H.-y., Xie, W., and Wu, G. (2018). Predicting the Occurrence of Channelized Debris Flow by an Integrated Cascading Model: A Case Study of a Small Debris Flow-Prone Catchment in Zhejiang Province, China. Geomorphol. 308, 78-90. doi:10.1016/j.geomorph.2018.01.027

Yen, B. C., and Lee, K. T. (1997). Unit Hydrograph Derivation for Ungauged Watersheds by Stream-Order Laws. J. Hydrologic Eng. 2, 1-9. doi:10.1061/ (asce) 1084-0699(1997)2:1(1)

Yin, Y., Cheng, Y., Liang, J., and Wang, W. (2016). Heavy-rainfall-induced Catastrophic Rockslide-Debris Flow at Sanxicun, Dujiangyan, after the Wenchuan Ms 8.0 Earthquake. Landslides. 13, 9-23. doi:10.1007/s10346015-0554-9

Zhang, J., and Li, J. (2018). Delay Failure Mechanism of Rainfall-Caused Shallow Landslide. Geotech Geol. Eng. 36, 2293-2304. doi:10.1007/s10706-018-0462-6

Zhang, Y., Cheng, Y., Yin, Y., Lan, H., Wang, J., and Fu, X. (2014). High-position Debris Flow: a Long-Term Active Geohazard after the Wenchuan Earthquake. Eng. Geology. 180, 45-54. doi:10.1016/j.enggeo.2014.05.014

Conflict of Interest: The authors declare that the research was conducted in the absence of any commercial or financial relationships that could be construed as a potential conflict of interest.

Copyright (๑) $2021 \mathrm{Yan}, \mathrm{Xu}, \mathrm{Lu}$, Zhou, Wang and Wang. This is an open-access article distributed under the terms of the Creative Commons Attribution License (CC $B Y)$. The use, distribution or reproduction in other forums is permitted, provided the original author(s) and the copyright owner(s) are credited and that the original publication in this journal is cited, in accordance with accepted academic practice. No use, distribution or reproduction is permitted which does not comply with these terms. 